\title{
An analysis of the legal environment of Chinese Enterprises' investment in Laos
}

\author{
ZhiYi Yin \\ International Business School \\ International Business School of YUFE \\ Kunming, China \\ 1243114375@qq.com
}

Yang Yang

International Business School

Yunnan University of Finance and Economics

Kunming, China

1347789768@qq.com

\author{
Yuan Ma \\ College of Accounting \\ Yunnan University of Finance and Economics \\ Kunming, China \\ 738112440@qq.com \\ XiaoHong Cun* \\ International Business School \\ Yunnan University of Finance and Economics \\ Kunming, China \\ 16990822@qq.com
}

\begin{abstract}
At present, there are a lot of Chinese enterprises to invest in Laos, and the actual legal environment of Laos is poor, so it is necessary to analyze the legal environment of Laos. In this article, at first, I will introduce current investment situation of Chinese enterprises in Laos, and then introduce the existing legal framework on foreign investment in Laos in detail, next, I would like to describe the existing problems in current legal system, combined with the introduction and analysis above, some suggestions will be presented for Chinese enterprises to invest in Laos.
\end{abstract}

Key words—Laos Foreign investment; laws Environment

\section{INTRODUCTION}

Study of Laos Foreign Investment law environment, Chinese scholars usually study, Investment Promotion Law of the Lao People's Democratic Republic, Law on the Promotion of Foreign Investment, Rules for the implementation of law on the Promotion of Foreign Investment, Lao people's democratic Republic tax laws. The existing literature most attention in studying in one law mentioned above, but lack of research of the legal environment of Laos as a whole, and the lack of legal research on the environmental protection and the protection of intellectual property rights, reference value for enterprise is not great.

\section{A DETAILED INTRODUCTION OF CHINESE ENTERPRISES' INVESTMENT IN LAOS}

\section{A. Present situation of Chinese enterprises Invest in Laos}

Since the beginning of twenty-first Century, relationships between China and Laos have maintained a healthy and stable development, under the guidance of the principle of "longterm stability, good neighbor friendship, mutual trust and overall development". Since September 2009, relations between the two countries have been enhanced to the comprehensive strategic partnership, the relations have entered the new period of accelerated development, bilateral cooperation in economic and trade, political, cultural, international and regional affairs continue to deepen. China is the second largest trading partner of Laos, in recent years, more and more Chinese funded enterprises decide to enter the Laos' market, the investment field is constantly expanding, and the way of investment tends to diversify. The main investment fields include minerals, hydropower, agriculture, forestry, real estate, park development, hotels, etc. In terms of trade, according to the Chinese statistics, in 2014, bilateral trade volume amounted to $\$ 3.614$ billion, increased $31.87 \%$, of which China's exports 18.43 U.S. dollar, increased 7.13\%, imports from the Laos, increased $73.56 \%$ [1].

In terms of Investment, according to the Chinese Ministry of Commerce statistics, in 2014, when the Chinese direct investment in Laos flows of \$ 1.027 billion. By the end of 2014 , China's direct investment stock of $\$ 4.491$ billion in Laos.

About labor contract, according to China's Ministry of Commerce statistics, in 2014, Chinese enterprises signed 94 new contracted project contracts in Laos, new contract amount of 36.90 billion and achieved a turnover of 23.28 billion; when dispatched various types of service personnel in the number of 11717. At the end of the year, there are 14815workers in Laos [2].

\section{B. Investment management institutions and foreign investment} procedures in Laos

The level of foreign investment management institutions in Laos is very high, reflecting the importance of the introduction 
of foreign capital. The level of Foreign Investment Management Committee in Laos is central, so the Prime Minister, Deputy Prime Minister and others make up the Commission. The permanent establishment of specific management investment is the domestic and foreign investment authority, which is under the Lao national planning and cooperation committee and administrate the foreign investment management promotion department, the project evaluation office and other agencies. Laos also has a domestic and Foreign Investment Promotion Authority (DDFI), which formerly known as the office of the Foreign Investment Management Committee (FIMC). DDFI is mainly responsible for the assessment of investment applications, and cooperation with the relevant ministries of Laos. The Department is also responsible for monitoring the investment projects approved by the domestic investment committee (CIC), and provide information to investors at home and abroad [3].

Laos' Foreign Investment management institutions continue to improve management efficiency. Foreign countries invest in Laos must be adopted "one-step" approval by the Bureau of investment management, the investment authority have obligation to review the feasibility study report and other documents that related to investment, and present project ideas to the investment management committee, as well as according to the legal procedure and the government's plan, directly sign a contract with foreign investors on behalf of the government [4]. To send, receive and approve all relevant applications and investment documents, and apply for a variety of licenses and so on, must be handled through the investment authority. The investment management committee has the right of convening other government departments and the relevant provinces and cities to discuss and approve investment projects jointly.

To solve the problem of too much investment commission charges link, slow approval reflected by foreign investors, the government stipulate in the foreign investment projects in Laos approval procedure regulations that "carry out the implementation of the" one door "service, cancel project approval fee and material fee and limit approval time. In accordance with the current regulations, the amount of investment that less than $\$ 100$ million, the processing time should be 15 working days; the amount of investment that more than 100 million dollars but less than the $\$ 500$ million, approval time should be 45 working days; the amount of investment that more than 100 million dollars but less than the $\$ 10$ million, the approval time should be 60 working days [5].

\section{AN OVERVIEW OF THE LEGAL STATUS OF FOREIGN INVESTMENT IN LAOS}

\section{A. Foreign investment legislation and foreign capital policy in Laos}

In July 1988, the Supreme People's Council of Laos implement and formulate the first specialized legislation to encourage and protect foreign investment -People's Democratic Republic of Lao the law of foreign investment in Laos ( referred to as the Laos Foreign Investment Law ). In March of the following year, in order to better implement the law, Laos Council of ministers has also developed a Law Implementation Rules of People's Democratic Republic of Lao for foreign Investment in Laos (referred to as the implementation rules ) [5], and set up the foreign investment management committee. In March 1994, Lao promulgated the revised the law of management and promotion of foreign investment in Laos, in March 2001 promulgated the Regulations on the implementation of the promotion and management of foreign investment law. The law on the basis of reciprocal and mutual benefits, encourage foreign investors investing in various fields and in a variety of ways in Laos, such as agriculture, forestry, industry, service industry, which also includes import and export trade, traffic, transportation, banking, insurance, hotels and tourism, etc.

The 2010 version of Laos Promotion of Investment Act, is merger by the original Domestic Investment Promotion Management Law and the promotion and management of foreign investment law in Laos, and in which eight points were revised and improved, such as: investment way, investment type and the examination and approval procedures, a station type service investment, investment guidance catalogue, preferential policies, specialized economic development zone investment as well as the central and local management function partition content. In July 8, 2014, Laos officially adopted the newly revised Laos to encourage foreign investment law. The new investment promotion law has made specific provisions for the industries that foreign governments have banned from investing, industries that are specifically controlled by the government and occupation that retained for the Lao citizens.

\section{B. Market access in Laos}

\section{1) Provisions of the investment industry}

In addition to the realm of endanger the stability of the country, serious impact on the environment and the health of the people and the national culture industry, the Lao government encourages foreign companies and individuals to invest in various industries and in various fields, according to the new investment promotion law mentioned above:

a) Industry that are banned to foreign investment: the production and sale of all kinds of weapons; various kinds of drug cultivation, processing and sale; production and sales of stimulant (special stipulated by the Ministry of health); production and sales of cultural articles that will corrode, destroy good customs and habits of the nationalities; to produce and sale chemicals and industrial wastes that are harmful to humans and the environment; sexual services; guides for foreigners.

b) Industries that are specifically controlled by the government: energy, water, telecommunications and transportation, wood and wood products, mineral resources and minerals, chemicals, food, medicine and edible wine, tobacco, building materials, transportation, cultural products, precious metals and education.

c) Occupation that retained for the Lao citizens: concentrated in the industrial, handicraft industrial, tourism department and food department [6].

2) Provisions of the investment mode 
Foreign investors can follow the agreement, according to the following three ways to invest in Laos: joint operation, joint ventures with Lao investors and foreign owned enterprises [7].

The joint operation of the agreement refers to the joint operation of the Lao investor and the foreign party without of establish a new legal person.

Joint venture is an enterprise which is established, registered and jointly owned by foreign investors and Lao investors in accordance with Lao law. The shares held by foreign investors shall not be less than $30 \%$ of the registered capital.

Foreign owned enterprises are enterprises that are independent of foreign investors in Laos, which can be a new legal person or a branch.

\section{LAOS' TAX POLICY}

\section{A. Tax system}

Laos' tax law applies to individuals, legal persons and foreigners that are permanent or temporary operation and living in Laos for living and business, and Laos' citizen who have a place of residence and business but go abroad for profitable income-generating activities. There are six categories of taxes in Laos, indirect taxes including value added tax and consumption tax, direct taxes including profit tax, income tax, lump-sum tax, environmental taxes and service fees. Tax related procedures for enterprises in Laos:

Tax time: tax time is before 31 December, but profit tax quarterly pay, personal income tax monthly pay;

Tax channels: according to Laos's law, corporate tax channel is enterprises directly go to the local tax registration department to pay;

Tax payment procedures: according to Lao law, the tax procedures for enterprises in Laos are directly to where the tax registration department to declare and pay;

Tax data: enterprises need to provide tax related materials, including: tax statements, invoices, foreign investment permits, business license.

\section{B. The main taxes and tax rates}

Consumption tax: the Laos's government stipulates: fuel, alcohol (alcohol), soft drinks, cigarettes, cosmetics, fireworks and playing cards, vehicles, motor boats, appliances, game machine (Taiwan), entertainment service, telecom service, lottery and gaming industry service 15 categories of goods and services provided project must pay the consumption tax, specific tax rate from $10 \%-110 \%$ [9].

Income tax: the Laos's government stipulates: salary, the cost of labor, dynamic property and real property income, intellectual property, patent, trademark and income must pay income tax, the specific tax rate to 30 million Kip is the tax point, 300thousand- 1.5 million Kip is $5 \%$, 1.5 million - 4 million kip is $10 \%, 4$ million -8 million kip for $15 \%, 8-15$ million Kip is above $20 \%$, more than 15 million Kip is $25 \%$. Foreigners have been assessed by the total income of 10\% [10].

Profit tax: according to $35 \%$ of the taxable profit (more than 60 million KIP) will be assessed.

VAT: when purchase products, consumers also need to pay an additional $10 \%$ input price products for value-added tax.

\section{LABOR EMPLOYMENT AND MANAGEMENT}

In employment of the staff, when joint ventures and wholly owned enterprises recruiting staff, Lao citizens should be the first. If it is necessary, with the consent of the people's Democratic Republic of Laos, the enterprise may also recruit foreigners. Foreigners working in the above enterprises must obey the laws of the Lao People's democratic republic. The Lao People's Democratic Republic allowed foreigners to work in Laos with their families. The rights, interests and responsibilities of the Lao citizens and foreigners working in the above enterprises shall be guaranteed by the labor contract.

\section{THE USE OF LAND}

Laos implement land public ownership, land ownership prohibit to be traded, the real estate market transactions is just land use right transactions. The State shall, in accordance with the law and planning, manage all land in a unified way, and ensure that use of the land with a purpose and efficiency.

Laos land law (1997 edition) states, nationwide land is divided into the following eight types: agricultural land, forest land, construction land, industrial land, traffic land, culture land, national defense land, public security land and water land [10]. Land law also stipulates that once considered necessary, can turn a land type into another, but before used for other objectives, it must first obtain permission from the relevant departments and shall not cause adverse social and natural environment influences.

\section{INTELLECTUAL PROPERTY}

In 1995, Lao government promulgated the trademark order and in 2008, promulgated the intellectual property law. Trademark order provides that individuals or legal persons in Laos can turn to the Lao Ministry of science and technology to apply for trademark registration [11]. Trademark protection period is 10 years, can be extended for another 10 years every time. Consecutive 5 years without the approval of the trademark registration or certificate expired, it will lose its effectiveness.

\section{CONCLUSION}

Legal construction of Laos starts late, the legal system exist many defects need to be improved, but Laos pay much attention to foreign legal framework construction, Laos not only has introduced a series of laws and regulations related to the promotion of foreign investment, but also has been modified to improve the existing laws, so the study of the Lao law should be dynamic, to be updated in a timely manner. Chinese enterprises should keep in mind that before, during 
and after enter Laos, pay more attention to the Laos law and the law of the study, try to avoid legal risks.

\section{ACKNOWLEDGEMENT}

My deepest gratitude goes foremost to Professor Cun xiaohong and $\mathrm{Li}$ lairu for their constant encouragement and guidance. They have walked me through all the stages of the writing of this thesis. Without their consistent and illuminating instruction, this thesis could not have reached its present form. I also owe my sincere gratitude to my friends and my fellow classmates who gave me their help and time in listening to me and helping me work out my problems during the difficult course of the thesis.

\section{REFERENCE}

[1] H.X. Zhao, "Analysis of China's investment opportunities in Vietnam, Laos and Burma," Yunnan University, 2015.

[2] S.J. Qiand and H.B. Jiang, "Study on Laos Foreign Investment Law," Hebei Law Science, 2009.

[3] P. Bu, "Study on the foreign investment law of Laos under the background of economic globalization," Nanjing Teachers University, 2006.

[4] F.G. Qu, and Y.F. Zhi, "With the foreign investment law in China compared the characteristics of legal system of foreign invested enterprises in Laos," Legal and economic, 2009.

[5] P. Kang, "Study on the legal system of foreign investment in Laos," WuHan University, 2005.

[6] T. Su, "The economic relations between Laos and China under the framework of China ASEAN free trade area cooperation," Jilin University, 2009.

[7] D.W. Du, "Research on the foreign policy of Laos," Jilin University, 2009.

[8] L.P. Chen, "Research on the legal issues of using foreign capital and environmental protection under the background of ASEAN economic integration," Anhui University, 2010.

[9] C.M. Su, "The prospects of the development of the relations between Laos and China," Shandong University, 2010.
[10] Annule, "Policy Research on the management of Chinese enterprises' investment in Laos," Guangxi University For Nationalities, 2011.

[11] Pannake, "Analysis on the environment of Laos attracting direct investment in China," Hunan University, 2012.

[12] B.L. Song, "Research on promoting investment law in Laos," Guangxi University, 2013

[13] D.W. Li, "Research on the process of using foreign capital to promote the process of industrialization," Kunming university of science and technology, 2013.

[14] Weila, "Research on Laos attracting foreign direct investment of Chinese Enterprises", Tianjin University,2013.

[15] J.C. Tan, and L.Y. Wei, "Overview of Laos investment law system," Foreign capital in China, 2013.

[16] H.B. Wang, "Research on the evolution and current situation of Laos to promote foreign investment policy and law," Kunming university of science and technology, 2014.

[17] Phouva, "Study on the economic diplomacy of Laos after liberation," China Foreign Affairs University, 2014.

[18] R. Rao, "Legal issues that should be paid attention to in the investment of Chinese enterprises in Laos -- A Perspective of Lao People's Democratic Republic Investment Promotion Law".

[19] H. Li, "Laos investment environment and investment advice in the coming years," Journal of Guangxi University (PHILOSOPHY AND SOCIAL SCIENCES), 2014.

[20] Keomaniwan Nanthasane, "Post Cold War Lao China policy and its influencing factors," East China Normal University, 2015.

[21] Shadala, "Laos foreign capital protection system," Legal system and society, 2016.

[22] F.G. Qiu, and X.H. Tang, "Comparative analysis of tax law system between Laos and Philippines -- Based on the study of Chinese enterprise" investment in Laos and Philippines," Legal system and economy, 2016.

[23] X. Luo, "A study on Laos's policy towards China in the early twentyfirst Century," Jilin University, 2015.

[24] "Lao People's Democratic Republic of China's foreign investment law in Laos".

[25] "Investment Promotion Law of Lao Peopl's Democratic Republic".

[26] "Rules for the implementation of the Lao People's Democratic Republic for the promotion and management of Foreign Investment Law".

[27] "Lao People's Democratic Republic National Tax Law". 